\title{
IMPLEMENTASI NILAI TABLIGH PADA TENAGA PENGAJAR DALAM PROSES BELAJAR MENGAJAR DI MADRASAH ALIYAH NEGERI MOJOKERTO 1)
}

\author{
Iffa Amalia \\ Mahasiswa Program Studi S1 Ekonomi Islam-Fakultas Ekonomi dan Bisnis-Universitas Airlangga \\ Email: icahollala@yahoo.com \\ Sri Herianingrum \\ Departemen Ekonomi Islam-Fakultas Ekonomi dan Bisnis-Universitas Airlangga \\ Email: sriheria@gmail.com
}

\begin{abstract}
:
Islam teaches every human being which have been blessed by Allah SWT with various advantages to be thankful for what they have by utilizing his/her ability through dig and developing his/her potential in a good way, so that it can be meaningful for him/herself as well as to other people. The teachers at school, which has been trusted by other parties to constantly, transfers his/her knowledge and conduct their pupil according to the characteristics of Rasulullah SAW so that they're able to reach success in that school, and of the characteristic is tabligh. The outcome of this research is, teachers have implemented tabligh on the teaching -learning process communicatively, it was proofed by the fulfillment of 5 indicators which are; communication, model, education, wisdom and firmness which caused the escalation of student's morality until today. The teachers which have implemented tabligh are able to create a pleasant and conducive class with Islamic ethics. The implementation of tabligh is able to create excellent and high quality human resources. The excellent and high quality human resources will be able to build his/her economic condition as well as build the nation's.
\end{abstract}

Keywords: Implementation, tabligh, school teach

\section{PENDAHULUAN}

Dalam perkembangan segala aspek kehidupan beberapa tahun terakhir ini membuat kebutuhan hidup manusia menjadi meningkat. Pada dasarnya kebutuhan hidup hanya menitik beratkan pada kebutuhan pokok meliputi makanan, pakaian, dan tempat tinggal yang layak. Seiring dengan perkembangan yang terjadi tersebut membuat kebutuhan yang muncul dari setiap individu mengalami peningkatan. Kondisi yang seperti ini menuntut peran dari setiap individu untuk berusaha agar segala kebutuhan hidupnya dapat terpenuhi dengan cara bekerja.
Manusia diciptakan sebagai makhluk yang paling sempurna diantara makhluk lain dengan diberi nafsu, naluri, akal, dan hati. P3El (2008:8) menyatakan manusia sering memiliki keterbatasan dalam memanfaatkan kemampuan yang dimilikinya sehingga tidak mampu memanfaatkan sumberdaya secara optimal.

Perekonomian negara yang baik ditopang oleh kualitas bangsa yang baik, maka dari itu dibutuhkan sumberdaya manusia yang berkualitas. Sehingga diperlukan tingkat pendidikan yang memadai agar berdampak baik bagi seluruh aspek. Sehubungan dengan

1) Jurnal ini merupakan sebagian dari skripsi yang ditulis oleh Iffa Amalia, NIM : 041014167, yang diuji pada tanggal 16 Juni 2015 
Undang-Undang No 12 Tahun Tentang Pendidikan Tinggi yang berstandar kebijakan pendidikan sekolah 12 tahun maka dari itu penelitian ini mengacu pada tamatan lulusan SMA. Sesuai berdasarkan Tabel 1.1 data presentase angkatan kerja di Jawa Timur menurut pendidikan tertinggi yang ditamatkan tahun 2013 dan 2014 menyatakan bahwa Iulusan SMA lebih banyak dibutuhkan oleh angkatan kerja dibandingkan Iulusan SMP dan SD.

Tabel 1.

Persentase Angkatan Kerja di Jawa Timur Menurut Pendidikan Tertinggi yang Ditamatkan Tahun 2013 \& 2014

\begin{tabular}{|c|c|c|c|c|c|c|}
\hline \multirow{2}{*}{$\begin{array}{c}\text { Tahu } \\
\mathbf{n}\end{array}$} & \multicolumn{5}{|c|}{ Pendidikan Tertinggi yang Ditamatkan } \\
\cline { 2 - 7 } & $\begin{array}{c}\text { SD ke } \\
\text { Bawa } \\
\mathbf{h}\end{array}$ & SLTP & SLTA & $\begin{array}{c}\text { Diplom } \\
\mathbf{a}\end{array}$ & $\begin{array}{c}\text { Universit } \\
\text { as }\end{array}$ & $\begin{array}{c}\text { Jumla } \\
\mathbf{h}\end{array}$ \\
\hline $\mathbf{( 1 )}$ & $\mathbf{( 2 )}$ & $\mathbf{( 3 )}$ & $\mathbf{( 4 )}$ & $\mathbf{( 5 )}$ & $\mathbf{( 6 )}$ & $\mathbf{( 7 )}$ \\
\hline 2013 & 52,03 & $\begin{array}{c}18,4 \\
3\end{array}$ & $\begin{array}{c}22,5 \\
6\end{array}$ & 1,39 & 5,59 & 100 \\
\hline 2014 & 23,77 & $\begin{array}{c}16,8 \\
\mathbf{1}\end{array}$ & $\begin{array}{c}39,4 \\
6\end{array}$ & 3,64 & 16,32 & 100 \\
\hline
\end{tabular}

Sumber: BPS Provinsi Jawa Timur, Sakernas 2013 dan 2014 (data diolah)

Islam mengajarkan pada setiap umat manusia yang telah deberikan kelebihan oleh Allah SWT untuk mensyukuri nikmatnya dengan cara memanfaatkan kelebihan yang dimiliki untuk menggali dan mengembangkan potensi dalam dirinya dengan baik dan benar sehingga mampu bermanfaat bagi dirinya sendiri dan orang lain. Sowardi (2000:4) menyebutkan bahwa sesungguhnya manusia yang berkarakter unggul harus bersifat lurus, kuat, dan tinggi. Pernyataan tersebut telah sesuai dengan apa yang telah di ajarkan oleh Islam yaitu harus beradab tinggi, atau ammar ma'ruf nahi mungkar atau berbuat kebaikan dan menentang kejahatan serta istiqomah kepada Allah SWT. Hal ini sesuai dengan firman Allah SWT :

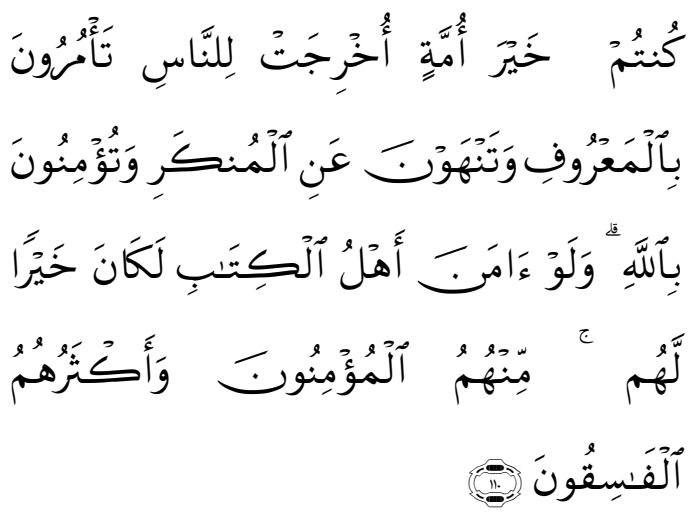

Kūntūm khayra ūmmatin ūkhrijat linnāsi ta'mūrūna bil ma'rūfi watanhawna 'anil mūnkari watūminūna billahi walaūāmana ahlūl kitābi lakāna khaira'l-lahūm. minhūmūl mū'minūna wa-akśarūhūmūl fāsiqūn.

"Kamu adalah umat yang terbaik yang dilahirkan untuk manusia, menyuruh kepada yang ma'ruf, dan mencegah dari yang munkar, dan beriman kepada Allah. Sekiranya ahli kitab beriman, tentulah itu lebih baik bagi mereka, di antara mereka ada yang beriman, dan kebanyakan mereka adalah orang-orang yang fasik". (QS.Ali Imron:110, Departemen Agama RI 2005:65)

Melaksanakan pekerjaan setiap manusia diwajibkan untuk bertindak dan berperilaku sesuai dengan etika dan moral.

Kesuksesan yang didapat oleh Rasulullah ini tidak serta merta datang dengan tiba-tiba. Banyak tantangan dan hambatan yang harus dilalui beliau untuk menjadi seorang pekerja yang sukses. Namun, (Kartajaya dan sula 2006:120) menyatakan ada lima kunci sukses Rasulullah dalam bekerja yaitu : 
1. Fathanah (cerdas)

2. Amanah ( terpercaya)

3. Shiddiq ( benar dan jujur )

4. Tabligh (komunikatif)

5. Istiqomah ( konsisten )

Kelima kunci sukses ini merupakan sifat-sifat Nabi Muhammad SAW yang telah banyak dikenal oleh masyarakat namun belum ada satupun yang benarbenar menerapkan sifat-sifat beliau tersebut.

Kualitas pendidikan yang baik akan menghasilkan output yang baik (Aziz, 2012:13). Hasil pendidikan yang memiliki kualitas yang baik dapat terlihat dari keberhasilan anak didik untuk menerapkan ilmu pengetahuan dan keahlian di kehidupan sehari-hari. Kualitas pendidikan dapat tercipta apa bila memiliki tenaga pengajar yang kompenten dibidang keahlian masingmasing sifat tabligh sangat dibutuhkan oleh tenaga pengajar agar mewujudkan siswa didik berkualitas sehingga menjadi sumberdaya insani yang dibutuhkan untuk pembangunan ekonomi terutama ekonomi islam.

Bekerja menjadi seorang pengajar dan guru bukanlah sebuah pekerjaan yang mudah. Kehadiran seorang tenaga pengajar adalah untuk memberikan pencerahan kepada manusia lainya, dalam hal ini murid-murid (Aziz, 2012:29). Peran seorang tenaga pengajar di sekolah untuk mengajarkan, membimbing, dan membina anak didik. Seorang pengajar dituntut untuk memiliki kesabaran dan ketentuan untuk menyampaikan ilmu yang dimilikinya. Maka dari itu seorang pengajar sering disebut pahlawan tanpa tanda jasa tugas dan kewajiban yang dimiliki seorang pengajar sangat besar yaitu mencerdaskan generasi muda penerus bangsa.

Untuk mengasilkan mutu dan kualitas pendidikan yang baik dalam pelaksanaan pembelajaran di sekolah, seorang tenaga pengajar harus mengamalkan nilai tabligh (komunikatif) dalam melaksanakan tugas dan kewajibanya. Tabligh yang memiliki arti Menyampaikan berguna dalam lingkup pendidikan. Penerapan nilai tabligh harus diterapkan oleh semua tenaga pengajar untuk memperoleh hasil yang baik dan sangat di perlukan oleh pengajar sebagai penyampaian ilmu-ilmu terhadap siswa yang diajarkan. Dalam sekolah Negeri berbasis Islam pelaksanaan nilai tabligh ini sudah harus dilakukan karena mengamalkan salah satu ajaran Islam.

Kenyataan yang terjadi saat ini masih banyak penyimpangan yang terjadi dalam proses pengajaran yang dilakukan oleh tenaga pengajar disekolah berbasis Islam penyimpangan mungkin tidak secara langsung disadari tetapi telah banyak dilakukan tenaga pengajar yang melakukan kegiatan belajar mengajar, misalnya seorang tenaga pengajar yang tidak datang tepat waktu sesuai dengan jadwal yang telah ditentukan oleh pihak sekolah, tidak memulai proses belajar 
mengajar didalam kelas dengan berdoa terlebih dahulu, seorang tenaga pengajar sering meninggalkan kelas pada saat berlangsungnya kegiatan belajar mengajar dan masih banyak penyimpangan yang mungkin terjadi. Hal ini berarti menunjukkan bahwa penerapan bekerja sesuai dengan nilainilai Islam belum benar-benar diterapkan oleh tenaga pengajar di sekolah berbasis Islam.

Adanya permasalahan ini perlu diketahui bagaimana kinerja sumberdaya manusia dengan implementasi nilai tabligh dalam diri seorang tenaga pengajar di sekolah yang juga berpengaruh terhadap kemajuan dan keberhasilan Madarasah Aliyah Negeri Mojokerto. Dengan berhasilnya Madrasah Aliyah Negeri Mojokerto dapat memproduksi generasi penerus bangsa yang bermutu dan siap membangun Negara dari segi perekonomian maupun pembangunan dari segala aspek lainnya.

Berdasarkan uraian diatas maka judul penelitian ini adalah "Implementasi Nilai Tabligh Dalam Meningkatkan Kinerja Tenaga Pengajar Di Madrasah Aliyah Negeri Mojokerto", karena dapat memeberikan pengetahuan bagi peneliti dan pihak - pihak terkait dalam skripsi ini tentang pentingnya pengamalan nilai tabligh dalam diri seorang pengajar yang dapat meningkatkan kinerja tenaga pengajar tersebut dalam sekolah berbasis Islam.
Berdasarkan uraikan diatas, maka rumusan masalah yang diambil dalam penelitian ini adalah apakah implementasi nilai tabligh meningkatkan kinerja tenaga pengajar di MADRASAH ALIYAH NEGERI MOJOKERTO?

Tujuan penelitian ini untuk mengetahui Implementasi Nilai Tabligh Dalam Meningkatkan Kinerja Pengajar di bidang pendidikan dalam sekolah berbasis islam, Apakah meningkatkan kinerja tenaga pengajar tersebut.

\section{TINJAUAN PUSTAKA}

\section{Manajemen Sumber Daya Manusia}

Sedarmayanti

(2007:13) menyatakan bahwa manajemen sumber daya manusia adalah kebijakan dan praktik menentukan aspek manusia atau sumber daya manusia dalam posisi manajemen. Sedangkan Ismail (2009:5) menyatakan pengertian sumber daya manusia pada dasarnya dibangun oleh dua konsep yakni konsep mengenai management dan konsep mengenai sumber daya manusia (human resources). Tujuan dari pengelolaan sumber daya manusia yang dimiliki.

Keberhasilan suatu konsep manajemen sumber daya manusia ini sangat tergantung kepada kemampuan dan keunggulan dari para pelaku yang ada didalam organisasi tersebut. Keunggulan yang dimaksud terlebih pada keadaan dimana tiap individu memiliki kemampuan dan karakter yang baik serta dapat lebih baik dari pada yang lain. 


\section{Bekerja}

Untuk mendapatkan ekonomi yang mapan atau hanya sekedar untuk memenuhi kebutuhan yang pada suatu saat membentuk tujuan-tujuan hidup yang akan dicapai manusia dituntut untuk mampu melakukan suatu aktivitas yang dapat mendorong tercapainya tujuan hidup mereka yaitu salah satunya dengan bekerja. Hampir di setiap kesempatan dapat terlihat bermacam-macam usaha setiap manusia untuk bekerja demi mencapai semua kebutuhan hidup sehingga mereka mampu mengaktualisasikan diri mereka sendiri.

$$
\text { Kerja merupakan cara bagi }
$$

manusia untuk mempertahankan penghidupan, minimal untuk memenuhi kebutuhan-kebutuhan pokoknya (Asifudin, 2004:79). Kerja artinya kegiatan melakukan sesuatu. Sehingga dapat diartikan bahwa bekerja adalah melakukan aktivitas sengaja, bermotif dan bertujuan. Pengertian dari bekerja sendiri terkait dengan penghasilan atau upaya untuk memperoleh hasil, baik berupa material maupun nonmaterial. Secara terminologi definisi daribekerja adalah aktivitas yang menjadi saran bagi manusia untuk menciptakan eksistensi dirinya agar menjadi lebih berarti.

\section{Bekerja Dalam Pandangan Islam}

Bekerja dalam Islam merupakan suatu kewajiban bagi seorang muslim. Bagi seorang muslim, makna bekerja berarti niat yang kuat untuk menghasilkan dan memberi hasil kerja yang optimal sesuai dengan kemampuan yang dimiliki oleh setiap individu. Tasmara (2002:25) menyatakan bahwa :

Bekerja bagi seorang muslim adalah suatu upaya yang sungguh - sungguh, dengan mengerahkan seluruh asset, piker, dan zikirnya untuk mengaktualisasikan atau menampakan arti diri sendiri sebagai hamba Allah yang harus menundukkan dunia dan menempatkan dirinya sebagai bagian dari masyarakat yang terbaik (khairu ummah) atau dengan kata lain dapat juga kita katakan bahwa hanya dengan bekerjan manusia itu memanusiakan dirinya.

$$
\text { Ada beberapa pendapat }
$$
mengenai bekerja dalam pandangan Islam. Bekerja dalam Islam merupakan suatu ibadah berarti ungkapan yang pengertiannya mencakup segala hal yang disukai dan diperintahkan oleh Allah SWT agar mendapatkan ridho-Nya. Betapa besarnya penghargaan Islam terhadap makna dari bekerja ini, sehingga setiap pekerjaan yang diberikan niat yang luhur semata-mata hanya untuk mendapatkan rahmat dan ridho dari Allah SWT akan mendapat perlakuan yang mulia dihadapan Allah SWT.

\section{Bekerja Dalam Bidang Pendidikan}

Bekerja di lingkungan pendidikan termasuk pekerjaan yang mempunyai beban berat. Undang-undang nomer 20 tahun 2003 tentang Sistem Pendidikan Nasional menyebutkan pendidikan merupakan usaha sadar dan terencana untuk mewujudkan suasana belajar dan 
proses pembelajaran agar peserta didik secara aktif mengembangkan potensi dirinya agar memiliki kekuatan spiritual keagamaan, serta keterampilan yang diperlukan dirinya, masyarakat, bangsa dan negara. Berdasarkan undangundang diatas terlihat jelas bahwa pendidikan merupakan upaya yang dilakukan secara sengaja dan terencana dalam upaya untuk meningkatkan kualitas manusia di Indonesia.

Perkembangan dunia secara global menuntut untuk menjadi sumber daya manusia yang unggul dengan cara menempuh pendidikan sampai jenjang tertinggi. Tanpa memiliki kemmapuan sumber daya manusia yang tinggi dan mampu bersaing dengan negara lain hanya akan membawa pada posisi yang tidak dapat memanfaatkan situasi yang ada terutama untuk mencapai perbaikan hidup.

Untuk memperoleh tujuan yang diinginkan oleh setiap negara guna menciptakan kondisi masyarakat yang merata di tatanan ekonomi dan segala aspek kehidupan dituntut peran dari seorang tenaga pengajar untuk menyalurkan ilmu yang diperoleh kepada anak didik. Agung (2010:9) menyatakan bahwa :

Tenaga pengajar atau guru dalam hal ini menjadi ujung tombak dalam memberikan proses pembelajaran kepada anak didiknya. Agar pendidikan dapat memenuhi harapan dalam meningkatkan pencapaian hasil yang memadai dan mempersiapkan kualitas sumber daya manusia yang sebaikbaiknya, maka terdapat tiga unsur yang sangat menentukan dalam proses pendidikan dan pengajaran yakni siswa, guru, dan kurikulum.

\section{Profesi Tenaga Pengajar}

Aziz (2012:19) menyatakan bahwa tenaga pengajar atau guru adalah manusia yang "berjuang" terus-menerus dan secara gradual, untuk melepaskan manusia dari kegelapan. Keberadaan tenaga pengajar di sebuah sekolah memiliki tanggung jawab yang sangat besar dengan peran dan fungsi sebagai tenaga pengajar. Profesi sebagai tenaga pengajar adalah profesi yang menanamkan nilai-nilai kebajikan ke dalam jiwa manusia dan membentuk kepribadian manusia yang baik. Tenaga pengajar merupakan ujung tombak dalam perubahan kehidupan bangsa dan negara.

\section{Fungsi Tenaga Pengajar}

Keberadaan seorang tenaga pengajar adalah untuk memberikan informasi ilmu dan pengetahuan kepada anak didik. Aziz (2012:29) menyatakan ada beberapa fungsi dari tenaga pengajar anatara lain :

\section{Mengajarkan}

Mengajarkan berarti menginformasikan pengetahuan kepada orang lain secara berurutan, langkah demi langkah.

\section{Membimbing/Mengarahkan} Membimbing memiliki arti memberikan petunjuk kepada orang yang tidak atau 
belum tahu (Aziz, 2012:31). Tenaga pengajar dengan fungsi sebagai pembimbing dan pengarah adalah tenaga pengajar yang menjalankan aktivitasnya dengan hati karena mengetahui yang menjadi sasaran utama fungsi profesionalnya adalah hati anak didik bukan sekedar otak anak didik.

3. Membina

Membina adalah berupaya dengan sungguh-sungguh untuk menjadikan sesuatu yang lebih baik dan terus lebih baik dari sebelumnya.

Semua fungsi tenaga pengajar ini saling berkesinambungan satu dengan yang lain, sehingga aspek membina ini tidak hanya menjadi tanggung jawab seorang tenaga pengajar tetapi juga menjadi tanggung jawab pihak-pihak yang berkepentingan dalam dunia pendidikan.

Untuk menjadi seorang tenaga pengajar yang profesional harus melaksanakan tiga fungsi tersebut dengan baik. Ketiga fungsi ini harus dilakukan oleh seorang tenaga pengajar di seluruh sekolah, baik sekolah negeri umum maupun sekolah negeri berbasis Islam. Hal ini ditujukan untuk mencapai hasil yang baik dalam pelaksanaan proses pembelajaran yang dilakukan oleh tenaga pengajar.

\section{Nilai - Nilai Bekerja Dalam Islam}

Keberadaan manusia di muka bumi ini pada dasarnya ditujukan untuk menjadi seorang khalifah yang ditugaskan oleh Allah SWT untuk memelihara dan memanfaatkan segala yang ada di muka bumi ini guna tercapainya kemaslahatan umat. Manusia hidup di dunia ini harus memiliki naluri untuk mempertahankan hidup dengan cara bekerja. Bekerja merupakan suatu kewajiban bagi setiap muslim untuk mampu memenuhi segala kebutuhan hidup baik secara rohani dan jasmani. Sebagai umat muslim yang patuh terhadap ajaran agama Islam sudah seharusnya dalam bekerja menerapkan dan mengamalkan nilai-nilai bekerja yang sesuai dengan syariat Islam.

Berpegang teguh pada nilai-nilai yang terdapat pada Al-Quran, Nabi Muhammad Saw melakukan segala pekerjaan secara profesional. Nilai-nilai tersebut menjadi suatu landasan yang dapat mengarahkan untuk tetap dalam koridor yang adil dan benar (Kartajaya, 2006). Sebagai seorang muslim yang berpegang teguh akan ajaran agama Islam sudah seharusnya dalam bekerja harus di landasi dengan nilai keadilan, kejujuran, transparansi, etika, dan moralitas menjadi dasar dalam melakukan setiap pekerjaan. Sesuai dengan firman Allah SWT :

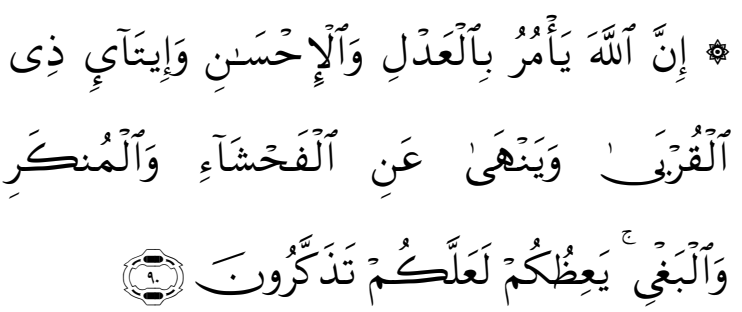
Inna'l-laha ya'mūrū bil'adli wal-iḥsāni waîtā-l ż̀ qūrbā wayanhā 'anil fahsyā-l wal mūnkari wal baghyi. Ya'iẓhūkūm la'allakūm tażakkarūn. 
"Sesungguhnya Allah menyuruh (kamu) Berlaku adil dan berbuat kebajikan, memberi kepada kaum kerabat, dan Allah melarang dari perbuatan keji, kemungkaran dan permusuhan. Dia memberi pengajaran kepadamu agar kamu dapat mengambil pelajaran." (QS. Al-Nahl:90, Departemen Agama RI 2005:278)

Ada beberapa nilai-nilai yang diterapkan oleh Nabi Muhammad Saw dalam melakukan suatu pekerjaan yang menjadikan Rasulullah sebagai pekerja yang tangguh dan sukses dalam bekerja. Nilai-nilai tersebut antara lain fathanah, amanah, shidiq, tabligh, dan istiqomah.

Ciri-ciri yang terkandung dalam FASTI (Fathanah, Amanah, Shidiq, Tabligh, Istiqomah) dapat dilihat dari perilaku sehari-hari dengan beberapa indikator sebagaimana Tabel 1.

Tabel 2.

INDIKATOR KARAKTER FASTI

\begin{tabular}{|c|c|c|c|c|}
\hline $\begin{array}{c}\text { FATHANA } \\
\mathrm{H} \\
\end{array}$ & AMANAH & SHIDIQ & TABLIGH & $\begin{array}{c}\text { ISTIQOM } \\
A H\end{array}$ \\
\hline $\begin{array}{l}\text { Kecerdas } \\
\text { an }\end{array}$ & Prinsip & Jujur & $\begin{array}{l}\text { Komunik } \\
\text { asi }\end{array}$ & $\begin{array}{l}\text { Percaya } \\
\text { diri }\end{array}$ \\
\hline$\| \mathrm{mu}$ & Harmoni & $\begin{array}{l}\text { Tawadh } \\
u\end{array}$ & Empati & Kuat \\
\hline Etika & Cinta & Loyal & Proaktif & $\begin{array}{l}\text { Sempurn } \\
\text { a }\end{array}$ \\
\hline $\begin{array}{l}\text { Profesion } \\
\text { al }\end{array}$ & Teliti & Sabar & $\begin{array}{l}\text { Pendidik } \\
\text { an }\end{array}$ & $\begin{array}{l}\text { Kontinuit } \\
\text { as }\end{array}$ \\
\hline Realistis & Analisa & Ikhlas & Motivasi & Resiko \\
\hline Rasional & $\begin{array}{l}\text { Kecepata } \\
n\end{array}$ & $\begin{array}{l}\text { Transpar } \\
\text { an }\end{array}$ & $\begin{array}{l}\text { Memimpi } \\
\mathrm{n}\end{array}$ & Menang \\
\hline Inisiatif & Fakta & Fakta & $\begin{array}{l}\text { Spontanit } \\
\text { as }\end{array}$ & Tujuan \\
\hline Belajar & $\begin{array}{l}\text { Tanggung } \\
\text { jawab }\end{array}$ & Hormat & Bijaksana & Visi \\
\hline Alasan & Respek & $\begin{array}{l}\text { Perbaika } \\
n\end{array}$ & $\begin{array}{l}\text { Pengaru } \\
\mathrm{h}\end{array}$ & $\begin{array}{l}\text { Komitme } \\
n\end{array}$ \\
\hline Solusi & Tepat janji & Mandiri & Melayani & Optimis \\
\hline Prestasi & $\begin{array}{l}\text { Wewenan } \\
\mathrm{g}\end{array}$ & Adil & Informasi & $\begin{array}{l}\text { Semang } \\
\text { at }\end{array}$ \\
\hline Inovasi & Jabatan & Terbuka & $\begin{array}{l}\text { Relations } \\
\text { hip }\end{array}$ & $\begin{array}{l}\text { Berkorba } \\
\mathrm{n}\end{array}$ \\
\hline Hasil & Misi & Teladan & $\begin{array}{l}\text { Kerja } \\
\text { sama }\end{array}$ & $\begin{array}{l}\text { Ketaata } \\
n\end{array}$ \\
\hline $\begin{array}{l}\text { Kreativita } \\
\mathrm{s}\end{array}$ & $\begin{array}{l}\text { Kehormat } \\
\text { an }\end{array}$ & Objektif & $\begin{array}{l}\text { Dukunga } \\
\mathrm{n}\end{array}$ & Berani \\
\hline Toleransi & Kepercay & & Teladan & Disiplin \\
\hline
\end{tabular}

\begin{tabular}{|l|l|l|l|l|}
\hline & aan & & \\
\hline Sumber : Toto Tasmara. 2001. Kecerdasan Ruhaniah
\end{tabular} (Transcendental Intelligece). Jakarta : Gema Insani, hal. 232

\section{Sifat - Sifat Wajib Rasulullah}

Seorang Rasul diutus oleh Allah SWT, memiliki sifat-sifat terpuji (akhlaqul karimah). Sifat-sifat nabi tidak akan mudah apabila ditiru tanpa pembelajaran sejak dini, tanpa adanya niat, serta tidak memiliki iman. Selain menjadi akhlak yang mulia seperti yang dijelaskan oleh Tasmara (2001:189), sifat-sifat Rasulullah tersebut dapat menjadi teladan bagi kita.

Rasulullah memiliki sifat wajib, yaitu :

\section{Fathanah}

Sifat fathanah ini juga akan menumbuhkan krativitas dan kemampuan untuk melakukan berbagai macam inovasi yang bermanfaat. Kreatif dan inovatif hanya mungkin dimiliki ketika seorang selalu berusaha untuk menambah berbagai ilmu pengetahuan dan informasi, baik yang berhubungan dengan pekerjaannya maupun perusahaan secara umum (Sula, 2006:130).

Salah satu ciri orang yang paling bertakwa adalah orang yang paling mampu mengoptimalkan pikirannya. Dalam Al-Quran, orang yang paling senantiasa mengoptimalkan potensi pikirnya biasa disebut ulul al-bab, yaitu orang yang iman dan ilmunya berinteraksi secara seimbang (Abdulrahim : 1995).

\section{Amanah}

Sifat nabi yang selanjutnya perlu diteladani oleh seorang pengajar adalah sifat amanah. Kata amanah sendiri 
memiliki arti dapat dipercaya. Makna lain dari amanah sendiri adalah bertanggung jawab dalam menjalankan tugas dan kewajiban yang diberikan dalam bekerja. Amanah bisa juga bermakna keinginan untuk memenuhi sesuatu sesuai dengan ketentuan. Amanah adalah titipan yang menjadi tanggungan, bentuk kewajiban atau utang yang harus kita bayar dengan melunasinya sehingga kita merasa aman atau terbebas dari segala tuntutan (Tasmara, 2002:95).

\section{Shiddiq}

Shiddiq berarti memiliki kejujuran dan selalu melandasi ucapan, keyakinan, serta perbuatan berdasarkan ajaran Islam. (Hafidhuddin dan Tanjung, 2003:72). Tasmara (2001:189-190) mengatakan bahwa :

Salah satu dimensi kecerdasan ruhani terletak pada nilai kejujuran yang merupakan mahkota kepribadian orangorang yang mulia yang telah dijanjikan Allah akan memperoleh limpahan nikmat dari-Nya. Selanjutnya kedudukannya disejajarkan dengan para nabi (shiddiqin nabiyaa) dan dijadikan rujukan untuk menjadi teman dalam meningkatkan kualitas hidup.

\section{Tabligh}

Tabligh adalah menyampaikan atau mengajak sekaligus memberikan contoh kepada orang lain untuk melakukan hal-hal yang benar di dalam kehidupan (M. Zama'syari, 2010). Dalam hal ini tabligh bisa berarti argumentatif dan komunikatif. Artinya bahwa seorang individu harus memiliki sifat argumentatif dan komunikatif dalam menyampaikan sesuatu hal. Apabila kita seorang marketer misalnya, maka kita harus mampu menyampaikan keunggulan-keunggulan produk dengan menarik dan tepat sasaran tanpa meninggalkan kejujuran dan kebenaran. Lebih dari itu, kita harus mempunyai gagasan-gagasan yang segar dan mampu mengkomunikasikan secara tepat dan mudah dipahami oleh siapapun yang mendengarkannya. Dengan begitu, orang lain yang mendengarkan dapat dengan mudah memahami pesan yang ingin disampaikan.

Nilai tabligh sendiri dapat diartikan oleh umat muslim dengan mengkomunikasikan dan menyampaikan segala sesuatu informasi dengan baik kepada siapapun. Orang yang memiliki dan menerapkan nilai tabligh ini akan menyampaikan segala sesuatu informasi dengan benar dan dengan tutur kata yang tepat. Sebagaimana firman Allah SWT :

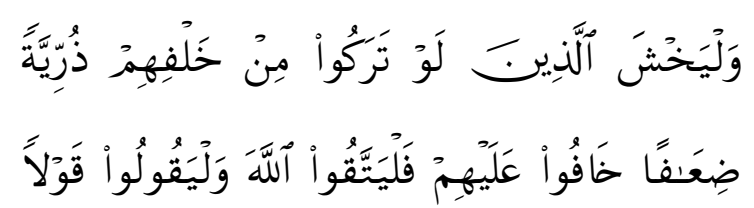

Wal yakhsyal lażina laū tarakūū min'khalfihim żürriyatan dhi'āfan khāfūū'alaihim fal yattaqūllaha wal yaqūūlūū qaūlan sadìdā.

"Oleh karena itu, hendaklah mereka bertaqwa kepada Allah dan hendaklah mereka mengucapkan perkataan yang benar (qaulan sadidan)." 
(QS. An-Nisa':9, Departemen Agama RI 2005:78)

\section{Istiqomah}

Istiqomah merupakan bentuk kualitas batin yang melahirkan sikap konsistensi dan teguh pendirian untuk menegakkan dan membentuk sesuatu menuju kondisi yang lebih baik daripada kondisi yang sebelumnya. Nilai istiqomah ini dapat dikatakan suatu kekuatan iman yang telah merasuk ke jiwa, sehingga tidak mudah terpengaruh, tidak mudah goyah dan tidak mudah putus asa atas permasalahan yang timbul dalam melakukan suatu pekerjaan.

Tasmara (2002 : 86) menyatakan bahwa pribadi muslim yang profesional dan berakhlak memiliki sikap konsisten yaitu kemampuan untuk bersikap secara taat atas, pantang menyerah dan mampu mempertahankan prinsip serta komitmennya walau harus berhadapan dengan resiko yang membahayakan diriya. Seseorang yang telah memiliki nilai istiqomah dalam hidupnya merupakan orang yang memiliki ketenangan yang luar biasa meskipun dalam kondisi tertekan sekalipun.

\section{Kinerja}

Sutarto (2010 : 59) yang mengutip pernyataan Maier (1965) memberikan batasan bahwa secara umum prestasi kerja diartikan sebagai suatu keberhasilan dari individu dalam suatu tugas dalam pekerjaannya. Swasto (1996 : 36-37) menyatakan bahwa secara umum prestasi kerja atau kinerja merupakan tindakan-tindakan atau pelaksanaan tugas yang telah diselesaikan oleh seseorang dalam kurun waktu tertentu dapat diukur. Hal ini dapat berkaitan dengan jumlah kualitas dan kuantitas pekerjaan yang dapat diselesaikan individu dalam kurun waktu tertentu.

Keberhasilan sebuah lembaga atau perusahaan dalam mencapai tujuan organisasi salah satunya ditentukan oleh kinerja tenaganya. Ukuran keberhasilan seseorang tenaga kerja biasanya dapat dilihat dari hasil kinerjanya dalam periode waktu tertentu. Tenaga kerja yang bekerja dengan baik pada periode waktu tertentu diharapkan dapat meningkatkan kinerja perusahaan secara keseluruhan, yang pada akhirnya membawa kesejahteraan bersama (Istijanto, 2005 : 181).

\section{Penilaian Kinerja}

Griffin (2004 : 429) menyatakan bahwa, Penilaian kinerja (performance appraisal) adalah sesuatu penilaian formal mengenal seberapa baik tenaga kerja melakukan pekerjaan mereka. Pendapat lain dikemukakan oleh Boone dan David (2007 : 432), Penilaian kinerja (performance appraisal) adalah sebuah evaluasi terhadap kinerja dari pekerjaan tenaga kerja, dengan cara membandingkan antara hasil aktual dengan hasil yang di inginkan.

Rivai (2005 : 3) menjelaskan bahwa, penilaian kinerja lebih dipandang sebagai suatu proses sosial dan proses komunikasi daripada hanya sebagai alat pengukur. Hasil penilaian dapat dilihat 
kinerja perusahaan yang tercermin oleh kinerja tenaga kerja atau dengan kata lain, kinerja merupakan hasil kerja konkret yang dapat diamati dan diukur (Rivai, 2010 : 549). Tujuan utama dari penelitian kinerja ialah untuk memotivasi tenaga kerja dan mencapai tujuan organisasi dan dalam mematuhi standar perilaku yang telah ditetapkan sebelumnya, agar membuahkan tindakan dan hasil yang diinginkan (Rudianto, 2006 : 311). Berdasarkan penilaian kinerja, manajer membuat keputusan objektif tentang kompensasi, promosi, kebutuhan pelatihan tambahan, dan pemutusan hubungan kerja (Boone dan David, 2007 : 432).

Jusmaliani (2011 : 112) menyatakan bahwa, ada lima pilihan siapa yang dapat melakukan penilaian kinerja yaitu:

1. Dilakukan oleh atasan langsung. Hampir semua sistem penilaian kinerja mengandalkan hal ini, karena atasan langsung berada pada posisi terbaik untuk mengamati dan melakukan evaluasi terhadap kinerja bawahannya. Kinerja bawahan memang menjadi tanggung jawab atasan langsung.

2. Menggunakan Peer Apprasial.

Dari beberapa studi (Dessler, 1997) ternyata penilaian yang dilakukan oleh rekan kerja (peer appraisal) ini cukup efektif dalam memprediksi keberhasilan manajemen masa depan dan memprediksi siapa yang akan dipromosikan.

3. Rating Committtees.
Banyak pemberi kerja yang sudah menggunakan cara ini dalam evaluasi kinerja karyawan. Biasanya komite terdiri dari atasan langsung karyawan ditambahi dengan 3-4 superisor lainnya.

4. Self-Rating.

Penilaian terhadap diri sendiri ini sering digunakan bebarengan dengan rating oleh atasan langsung. Masalah mendasar dari cara ini adalah karyawan biasanya menilai dirinya lebih tinggi daripada penilaian atasannya.

5. Penilaian oleh bawahan.

Sekarang mulai banyak perusahaan yang membiarkan bawahan menilai atasan langsungnya secara anonym, cara ini dsebut juga dengan upward feedback.

\section{Tujuan Penilaian Kinerja}

Penilaian kerja ini dilakukan dengan tujuan agar terjadi peningkatan kerja dari setiap pegawai di suatu lembaga atau instansi menjadi lebih baik dari sebelumnya. Maka dari itu tujuan harus secara tegas dan jelas sehingga manfaat dari penelitian ini dapat dirasakan oleh para pegawai yang bersangkutan. Selain itu dengan adanya sutu penilain kerja sebuah lembaga atau organisasi akan mapu menentukan keputusan apa yang akan diambil berhubungan dengan pengembangan sumber daya manusia yang dimiliki dengan memberikan pelatihan atau pembekalan agar terjadi peningkatan mutu kinerja dari pegawai tersebut.

Berdasarkan beberapa pendapat diatas penilaian kerja pada dasarnya 
merupakan penilaian yang sistematis terhadap kerja pegawai potensi pegawai dalam rangka pengembangan diri untuk kepentingan lembaga atau instansi tertentu. Ada beberapa hal dalam kerja seorang pegawai yang dapat dinilai. Menurut Heidrahman (1990: 126) faktorfaktor prestasi kerja yang perlu dinilai adalah sebagai berikut:

1) Kuantitas Kerja

Banyaknya hasil kerja sesuai dengan waktu kerja yang ada, yang perlu diperhatikan bukan ahsil rutin tetapi seberapa cepat pekerjaan dapat diselesaikan.

2) Kualitas Kerja

Mutu hasil kerja yang didasarkan pada standar yang ditetapkan. Biasanya diukur melalui ketetapan, ketelitian, keterampilan, keberhasilan hasil kerja.

3) Keandalan

Dapat atau tidaknya karyawan diandalkan adalah kemampuan memenuhi atau mengikuti instruksi, inisiatif, hati-hati, kerajinan dan kerjasama.

4) Inisiatif

Kemampuan mengenali masalah dan mengambil tindakan korektif, memberikan saran-saran untuk peningkatan dan menerima tanggung jawab menyelesaikan.

5) Kerajinan

Kesediaan melakukan tugas tanpa adanya paksaan dan juga yang bersifat rutin.

6) Sikap
Perilaku karyawan terhadap perusahaan atau atasan atau teman kerja.

7) Kehadiran

Keberadaan karyawan di tempat kerja untuk bekerja sesuai dengan waktu/jam kerja yang telah ditentukan.

\section{Kinerja Dalam Pandangan Islam}

Islam mewajibkan setiap umatnya untuk melaksanakan ibadah, baik ibadah langsung (hablumminaAllah) dan ibadah tidak langsung (hablumminannas). Bekerja merupakan bagian ibadah tidak langsung (hablumminannas) sekaligus merupakan kewajiban setiap individu muslim, karena dengan bekerja setiap muslim akan mengaktualisasikan kemuslimannya makhluk ciptaan Allah SWT yang paling sempurna dan mulia diatas dunia.

Dan Islam juga mengajarkan umatnya untuk bekerja dengan sungguhsungguh dan sepenuh hati untuk mendapatkan ridho Allah SWT sehingga mampu menghasilkan sebuah hasil kerja yang membanggakan. Kinerja yang baik menurut pandangan Islam merupakan suatu hasil kerja yang dicapai oleh seorang pekerja dalam suatu lembaga atau instansi yang dilakukan dengan penuh rasa tanggung jawab, tidak melanggar ajaran-ajaran Islam, dan sesuai dengan etika dan moral (Asifudin, 2004 : 124). Dalam ajaran Islam seorang pekerja yang melaksanakan tugas dan kewajiban saat bekerja harus selalu melibatkan ilmu pengetahuan dan teknologi sehingga kualitas kinerja berdasarkan pandangan 
Islam berbeda dengan kualitas kinerja biasa.

Dalam penelitian yang dilakukan Diana (2011 : 26-40) menjelaskan bahwa dimensi kinerja dalam teori modern sangat sesuai dengan tuntunan Islam, dimensi yang dimaksud adalah :

1. Kuantitas

Kinerja yang baik menurut Islam bias dilihat dari sisi seberapa banyak zakat dan sedekah yang dikeluarkan dari hasil kerja yang diperoleh. Mengeluarkan zahat harus memenuhi nisab dan haul. Ketentuan nisab ini mengajarkan bahwa seorang muslim jika ingin mempunyai predikat muzakki atau tangan diatas yang dinilai sangat mulia dihadapan Allah SWT, maka seorang muslim harus berusaha kerass mencapai kuantitas tertentu.

2. Kualitas

Karyawan yang berkinerja baik adalah orang yang mengerjakan tugasnya dengan penuh ikhlas, sehingga karyawan tersebut menyelesaikan pekerjaannya tersebut dengan penuh suka cita dan ramah.

\section{Kreativitas}

Allah SWT telah menganjurkan umat-Nya untuk berussaha dan kreatif agar berhasil dalam menggapai apa yang menjadi cita-citanya. Tanpa usaha dan kreativitas maka akan menjadi tujuan setiap individu manusia tidak akan tercapai.

4. Keandalan

Kinerja yang handal berarti rterdapat kerjasama tim didalamnya. Kerjasama tim dalam Islam sangat dianjurkan, agar dapat memperoleh hasil kerja (kinerja) yang maksimal.

5. Istiqamah Waktu

Kinerja yang memuaskan dalam pandangan Islam dapat dilihat dari efisiensi dalam penggunaan waktu, karena Islam mengajarkan agar umatnya tidak membuang-buang waktu dengan mengerjakan suatu pekerjaan yang tidak bermanfaat.

\section{Pendekatan Penelitian}

Penelitian ini menggunakan pendekatan kualitatif. Penelitian yang dilakukan dengan pendekatan kualitatif ini harus terjadi secara natural untuk mencari dan menemukan pemahaman tentang suatu fenomena yang terjadi dalam suatu latar dengan konteks tertentu. Proses yang dilakukan dalam penelitian kualitatif ini harus terjadi secara alamiah yang tidak mewajibkan peneliti agar terlebih dahulu membentuk konsep atau teori tertentu terhadap penelitiannya.

Berkaitan dengan tujuan dan rumusan masalah penelitian yang dijelaskan diatas, metode yang digunakan dalam penelitian ini adalah metode studi kasus yang bersifat eksploratoris. Metode studi kasus bersifat ekploratori lebih cenderung pada penelitian yang bersifat untuk melakukan ekslorasi terhadap penelitian yang sedang diteliti sehingga mampu untuk memperoleh jawaban secara mendalam tentang permasalahan yang memiliki tipe pertanyaan "bagaimana". Yin (2009:18) 
berpendapat bahwa suatu penelitian empiris yang menyelidiki fenomena dalam konteks kehidupan nyata,bilamana batasbatas antara fenomena dengan konteks tidak tampak dengan tegas dan multisumber digunakan. Metode studi kasus ini digunakan karena bertujuan untuk mengungkap dan mengetahui bagaimana peran nilai tabligh dalam meningkatkan kinerja tenaga pengajar di MADRASAH ALIYAH NEGERI MOJOKERTO.

Ruang lingkup penelitian ini hanya terbatas terhadap pengamalan nilai tabligh oleh tenaga pengajar sehingga akan menghasilkan sebuah kinerja oleh pengajar tersebut. Pengamalan nilai tabligh dalam hal ini mengenai bagaimana seorang tenaga pengajar mampu untuk melaksanakan tugas dan kewajibannya sebagai seorang guru di sekolah yang menjadi panutan bagi anak dididknya dan mampu menjadikan anak didiknya sebagai generasi yang unggul dan berguna bagi diri sendiri dan kehidupan bermasyarakat.

Jenis data yang digunakan dalam penelitian ini adalah data primer dan data sekunder. Data primer adalah data yang diperoleh dari individu atau perorangan, seperti hasil wawancara, dokumentasi, dan observasi langsung dari lapangan sehingga datanya banyak berwujud tindakan dari obyek penelitian. Dalam penelitian ini data primer diperoleh dengan cara melakukan wawancara dan observasi yang mendalam terhadap tenaga pengajar di MADRASAH ALIYAH NEGERI MOJOKERTO.

Teknis analisis dalam penelitian ini akan dilakukan dengan pendekatan analisis kualitatif deskriptif. Analisis tersebut bertujuan untuk menganalisis data studi kasus dengan membuat penjelasan (naratif) dan menggambarkan (deskripsi) kasus yang bersangkutan.

Penelitian ini menggunakan triangulasi teknik dan triangulasi sumber. Menurut Sugiyono (2013:83) triangulasi teknik dan triangulasi sumber adalah triangulasi teknik peneliti menggunakan teknik pengumpulan data yang berbeda-beda untuk mendapatkan data dari sumber yang sama. Peneliti menggunakan dokumentasi untuk sumber data yang sama. Sedangkan triangulasi sumber adalah untuk mendapatkan data dari sumber yang berbeda-beda dengan teknik yang sama.

Prosedur Pengumpulan Data Yin (2009: 101) berpendapat bukti atau data untuk keperluan studi kasus bisa berasal dari enam sumber, yaitu dokumentasi, rekaman arsip, wawancara, pengamatan langsung, observasi partisipan, dan perangkat-perangkat fisik. Keenam sumber data tersebut dapat dijelaskan sebagai berikut :

1. Dokumentasi

Penelusuran data melalui dokumen dianggap penting karena dapat mendukung dan menambah bukti dari sumber lain. Selain itu dokumen juga dapat menambah informasi dari sumber 
lainnya. Dokumen juga perlu digunakan secara hati-hati dan tidak asal diterima dari tempat mengambilnya.

2. Wawancara

Wawancara merupakan sumber informasi yang sangat penting dalam studi kasus. Secara keseluruhan, wawancara merupakan sumber bukti yang esensial bagi studi kasus, karena studi kasus umumnya berkenaan dengan urusan kemanusiaan (Yin, 2009:111). Dalam melakukan wawancara peneliti dapat melakukan dengan beberapa tipe yaitu wawancara tipe open-ended, wawancara terfokus, dan wawancara terstruktur. Ketiganya memiliki fungsi yang berbeda sesuai dengan kepentingan peneliti seberapa jauh untuk menggali informasi dari informan.

\section{Observasi Langsung}

Pengumpulan data dalam studi kasus juga dapat dilakukan dengan cara observasi langsung. Observasi ini dapat dimulai dari pengumpulan data yang dilakukan secara formal hingga yang kausal. Bukti dari observasi langsung ini seringkali menjadi informasi tambahan tentang topik yang sedang diteliti.

4. Perangkat-Perangkat Fisik

Sumber bukti terakhir yang meliputi peralatan teknologi, alat, pekerjaan seni, atau bukti fisik lainnya. Perangkat tersebut dikumpulkan sebagai bagian dari kunjungan lapangan dan telah digunakan secara luas dalam penelitian antropologi (Yin, 2009:117).

\section{HASIL DAN PEMBAHASAN}

Sejarah Singkat Madrasah Aliyah Negeri Mojokerto

Sejarah singkat MAN Mojokerto bermula dari suatu lembaga Pendidikan Guru Agama Islam (PGA) yang bertujuan untuk memenuhi kebutuhan guru pendidikan agama Islam di sekolah-sekolah rendah negeri. Hal ini berdasarkan surat keputusan bersama menteri Pendidikan dan Kebudayaan dengan menteri Agama pada tanggal 2 Desember 1946 no.1142/BH.A tentang penyediaan guru agama secara kilat dan cepat, sehingga ditetapkan rencana pendidikan guru agama Islam jangka pendek dan jangka panjang. Untuk mewujudkan rencana tersebut, maka pada tanggal 16 Mei 1948 mulai didirikan Sekolah Guru Hakim Islam (SGHI) dan Sekolah Guru Agama Islam (SGAI). Selanjutnya berdasarkan ketetapan menteri agama tertanggal 15 Agustus 1951 no. 7 SGAl diubah menjadi Pendidikan Guru Agama (PGA 5 tahun) yang siswanya berasal dari lulusan sekolah rendah atau madrasah rendah. Berdasarkan surat ketetapan menteri agama tanggal 21 Nopember 1953 no. 35, lama belajar di PGA ditambah 1 tahun, sehingga menjadi 6 tahun, dan diubah menjadi dua bagian, yaitu, Pertama: Pendidikan Guru Agama Pertama (PGAP), lama belajarnya 4 tahun ( kelas $1 \mathrm{~s} / \mathrm{d}$ kelas 4) dan Kedua: Pendidikan Guru Agama Atas (PGAA), lama belajarnya 2 tahun (kelas 5 dan kelas 6 ). Selanjutnya, pada tahun ajaran 1958/1959 
PGAP dan PGAA dilebur menjadi PGAN 6 TAHUN Mojokerto.

Perkembangan berikutnya, dengan adanya surat keputusan Menteri Agama tanggal 16 Maret 1978 no. 16, PGAN 6 tahun di pecah lagi menjadi dua lembaga pendidikan yaitu,Pertama: Kelas 1 s/d 3 menjadi Madrasah Tsanawiyah Negeri (MTsN) Mojokerto, dan Kedua: Kelas $4 \mathrm{~s} / \mathrm{d} 6$ menjadi Pendidikan Guru Agama Negeri (PGAN) Mojokerto. Selanjutnya berdasarkan Keputusan Menteri Agama no. 42 tanggal 1 Juli 1992 PGAN Mojokerto beralih fungsi menjadi Madrasah Aliyah Negeri (MAN) Mojokerto. PGAN Mojokerto telah mencapai kejayaan, hal ini berkaitan dengan keberhasilan outputnya yang dominan di tengah-tengah mansyarakat. Rata-rata alumni PGAN Mojokerto menjadi orang yang berpengaruh di masyarakat. Selain itu juga banyak yang menjadi penjabat penting di Lingkungan Departemen Agama maupun Departemen lain. Harapan ke depan setelah PGAN Mojokerto beralih fungsi ke MAN Mojokerto dari semua komponen yang ada barang tentu ingin mempertahankan citra lembaga pendidikan favorit yang berada di jalan RA Basuni 306 Sooko Mojokerto ini. MAN Mojokerto adalah sebagai lembaga pendidikan umum ditingkat menengah yang diselenggarakan oleh Kementerian Agama yang mempunyai keunggulan dibidang pemahaman agama Islam. Secara fisik citra yang ditampilkan adalah bernafaskan Islam, sehingga terkesan berwibawa, sejuk, rapi dan indah.
Cerminan pokok yang ditampilkan kampus MAN Mojokerto adalah Islami dan terkesan modern, serta dihuni oleh orang-orang yang dekat dengan Allah SWT, ramah terhadap sesama, santun, selalu tersenyum, serta peduli terhadap lingkungannya.

Ditinjau dari kelembagaan, MAN Mojokerto mempunyai tenaga akademik yang handal dalam pemikiran, memiliki manajemen yang kokoh yang mampu menggerakkan seluruh potensi untuk mengembangkan kreatifitas civitas akademika MAN Mojokerto, serta memiliki kemampuan antisipatif masa depan dan proaktif. Selain itu MAN Mojokerto memiliki pimpinan yang mampu mengakomodasikan seluruh potensi yang dimiliki menjadi kekuatan penggerak lembaga secara menyeluruh. (http://www.mansookomojokerto.sch.id) 
STRUKTUR ORGANISASI Madrasah Aliyah Negeri Mojokerto

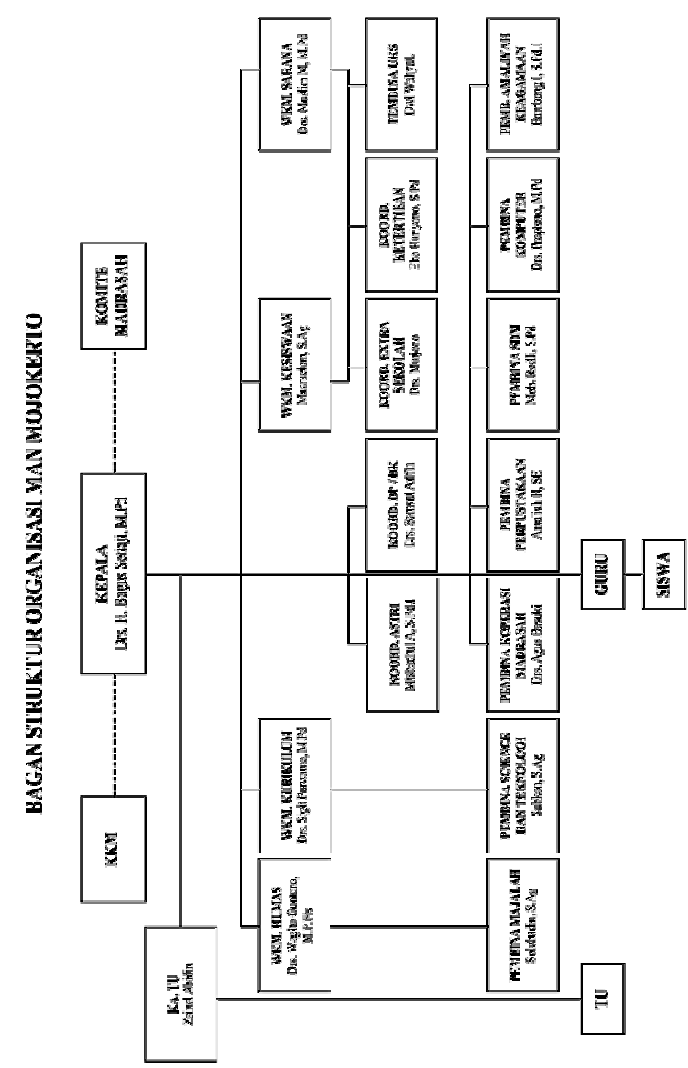

\section{Deskripsi Hasil Penelitian}

Deskripsi hasil penelitian ini akan menguraikan tentang berbagai temuan yang diperoleh dari lapangan, yaitu hasil dari wawancara dan observasi partisipatif pasif pada informan. Peneliti membuat daftar siapa saja yang akan diteliti sebagai informan, setelah itu peneliti mendatangi satu persatu informan yang akan diteliti dan menyampaikan maksud dan tujuan kedatangan peneliti. Setelah itu peneliti menanyakan beberapa pertanyaan kepada para informan yang berhubungan dengan Implementasi Nilai Tabligh Dalam Meningkatkan Kinerja Tenaga Pengajar Di Madrasah Aliyah Negeri Mojokerto. Namun dalam hal ini peneliti tidak terlibat langsung dalam kegiatan yang dilakukan informan. Penelitian ini di lakukan mulai tanggal 10 Februari 2015 hingga 23 Februari 2015. Tabel 3 dibawah ini adalah jadwal pelaksanaan wawancara dan observasi langsung yang dilakukan terhadap takmir yang bersangkutan.

Tabel 3.

Jadwal Pelaksanaan Wawancara dan Observasi Langsung pada Guru Madrasah Aliyah Negeri Mojokerto

\begin{tabular}{|c|c|c|c|}
\hline $\begin{array}{l}\text { Tangg } \\
\text { al }\end{array}$ & Nama & Pekerjaan & Tempat \\
\hline $\begin{array}{l}10 \\
\text { Februa } \\
\text { ri } 2015\end{array}$ & $\begin{array}{l}\text { Drs.Prapto } \\
\text { no, M.Pd }\end{array}$ & $\begin{array}{l}\text { Pengajar } \\
\text { Mata } \\
\text { Pelajaran } \\
\text { Fisika }\end{array}$ & $\begin{array}{l}\text { Ruang } \\
\text { Tata Usaha } \\
\text { (TU) } \\
\text { Madrasah } \\
\text { Aliyah } \\
\text { Negeri } \\
\text { Mojokerto }\end{array}$ \\
\hline $\begin{array}{l}10 \\
\text { Februa } \\
\text { ri } 2015\end{array}$ & $\begin{array}{l}\text { Roy Yuhan } \\
\text { Saputro, } \\
\text { S.Pd }\end{array}$ & $\begin{array}{l}\text { Pengajar } \\
\text { Mata } \\
\text { Pelajaran } \\
\text { Bahasa } \\
\text { Mandari } \\
\text { dan } \\
\text { Jepang }\end{array}$ & $\begin{array}{l}\text { Di } \\
\text { Perpustaka } \\
\text { an } \\
\text { Madrasah } \\
\text { Aliyah } \\
\text { Negeri } \\
\text { Mojokerto }\end{array}$ \\
\hline $\begin{array}{l}12 \\
\text { Februa } \\
\text { ri } 2015\end{array}$ & $\begin{array}{l}\text { Yulia } \\
\text { Pratitis } \\
\text { Yusuf, S.Pd }\end{array}$ & $\begin{array}{l}\text { Pengajar } \\
\text { Mata } \\
\text { Pelajaran } \\
\text { Bahasa } \\
\text { Jepang }\end{array}$ & $\begin{array}{l}\text { Ruang } \\
\text { Guru } \\
\text { Madrasah } \\
\text { Aliyah } \\
\text { Negeri } \\
\text { Mojokerto }\end{array}$ \\
\hline $\begin{array}{l}12 \\
\text { Februa } \\
\text { ri } 2015\end{array}$ & $\begin{array}{l}\text { Drs.Buban } \\
\text { a, M.Pd }\end{array}$ & $\begin{array}{l}\text { Pengajar } \\
\text { Mata } \\
\text { Pelajaran } \\
\text { Sejarah }\end{array}$ & $\begin{array}{l}\text { Ruang } \\
\text { Guru } \\
\text { Madrasah } \\
\text { Aliyah } \\
\text { Negeri } \\
\text { Mojokerto }\end{array}$ \\
\hline $\begin{array}{l}16 \\
\text { Februa } \\
\text { ru } 2015\end{array}$ & $\begin{array}{l}\text { Sih Idi } \\
\text { Retnani, } \\
\text { S.Pd }\end{array}$ & $\begin{array}{l}\text { Pengajar } \\
\text { Mata } \\
\text { Pelajaran } \\
\text { Ekonomi }\end{array}$ & $\begin{array}{l}\text { Ruang } \\
\text { Guru } \\
\text { Madrasah } \\
\text { Aliyah } \\
\text { Negeri } \\
\text { Mojokerto }\end{array}$ \\
\hline $\begin{array}{l}16 \\
\text { Februa } \\
\text { ri } 2015\end{array}$ & $\begin{array}{l}\text { Ngatiman, } \\
\text { S.Pd.,M.Sc }\end{array}$ & $\begin{array}{l}\text { Waka } \\
\text { Kurikulum } \\
\& \\
\text { Pengajar }\end{array}$ & $\begin{array}{l}\text { Ruang } \\
\text { Guru } \\
\text { Madrasah } \\
\text { Aliyah }\end{array}$ \\
\hline
\end{tabular}




\begin{tabular}{|c|c|c|c|}
\hline & & $\begin{array}{l}\text { Mata } \\
\text { Pelajaran } \\
\text { Matemati } \\
\text { ka }\end{array}$ & $\begin{array}{l}\text { Negeri } \\
\text { Mojokerto }\end{array}$ \\
\hline $\begin{array}{l}18 \\
\text { Februa } \\
\text { ri } 2015\end{array}$ & $\begin{array}{l}\text { Dra.Dewi } \\
\text { Aisyah }\end{array}$ & $\begin{array}{l}\text { Pengajar } \\
\text { Mata } \\
\text { Pelajaran } \\
\text { Biologi }\end{array}$ & $\begin{array}{l}\text { Ruang } \\
\text { Guru } \\
\text { Madrasah } \\
\text { Aliyah } \\
\text { Negeri } \\
\text { Mojokerto }\end{array}$ \\
\hline $\begin{array}{l}23 \\
\text { Februa } \\
\text { ri } 2015\end{array}$ & $\begin{array}{l}\text { Dra.Bagus } \\
\text { Setiaji, } \\
\text { M.Pd }\end{array}$ & $\begin{array}{l}\text { Kepala } \\
\text { Sekolah \& } \\
\text { Pengajar } \\
\text { Mata } \\
\text { Pelajaran } \\
\text { Bahasa } \\
\text { Inggris }\end{array}$ & $\begin{array}{l}\text { Ruang } \\
\text { Kepala } \\
\text { Sekolah } \\
\text { Madrasah } \\
\text { Aliyah } \\
\text { Negeri } \\
\text { Mojokerto }\end{array}$ \\
\hline
\end{tabular}

Sumber: hasil olah data

Hal-hal yang perlu dirinci ialah mengenai aspek-aspek key performance Indikator Tabligh yakni meliputi :

1) Komunikasi

2) Teladan

3) Pendidikan

4) Bijaksana

5) Melayani

Hasil pengumpulan data selengkapnya dan bukti wawancara terdapat pada lampiran.

Pembahasan Implementasi Nilai Tabligh pada Tenaga Pengajar dalam Proses Belajar Mengajar Di Madrasah Aliyah Negeri Mojokerto

\section{a. Komunikasi}

Pengamalan aspek komunikasi sebagai bagian dari nilai tabligh dilakukan oleh semua informan dari dengan baik. Hal ini terlihat dari hasil wawancara dan analisis yang menunjukkan kegiatan yang dilakukan oleh informan yang mengacu kepada pengamalan nilai aspek tabligh oleh tenaga pengajar dalam proses pembelajaran. Tenaga pengajar yang memiliki komunikasi baik juga mampu membantu anak didik lebih dapat memahami mata pelajaran secara mendalam serta dapat menciptakan keharmonian pada saat belajar mengajar. Hal ini yang mengharuskan seorang tenaga pengajar untuk memiliki komunikasi yang baik sebagaimana yang telah diungkapkan para informan.

\section{b. Teladan}

Berdasarkan hasil wawancara dan analisis terlihat jelas berbgai macam teladan yang diberikan oleh pengajar pada anak didiknya. Pengamalan aspek teladan telah dilakukan oleh semua informan dengan baik. Semua informan menjadi teladan dan contoh yang baik bagi anak didiknya dengan harapan dapat melahirkan anak didik yang berakhlak mulai dan berbudi luhur bagi bangsa dan negara.

\section{c. Pendidikan}

Berdasarkan hasil wawancara dan analisis dapat dilihat bahwa semua informan telah mengamalkan aspek pendidikan dengan standar pendidikan yang dimiliki hanya 3 dari 8 informan yang masih jenjang pendidikan S1 dan selebihnya 5 informan pendidikannya sudah jenjang S2. Membuktikan bahwa semua informan tenaga pengajar mengutamakan aspek pendidikan dan selalu ingin meng upgrade pendidikannya supaya ilmu yang semua informan berikan pada anak didiknya itu semakin baik sehingga dapat menghasilkan anak didik 
yang semakin cerdas, tangkas, dan berkompetensi.

\section{d. Bijaksana}

Berdasarkan Tabel 4.6 sikap bijaksana telah mampu ditunjukkan oleh semua informan sebagai tenaga pengajar. Sikap bijaksana yang berasal dari kata hakamayahkumu-hukman-wahikmatan yang berarti teliti, bijak atau arif. Guru yang bijaksana adalah guru yang mampu mengendalikan dirinya dengan baik. Segala tingkah lakunya mencerminkan sosok yang arif dan bijaksana sehingga dapat dipercaya oleh murid-muridnya. Luhur budinya dan lurus ucapannya. Guru yang bijak memandang muridnya sebagai bagian tak terpisahkan dari hidupnya karena itu ia memperlakukan mereka dengan sebaik-baiknya. Ia tidak menganggap mereka sebagi orang lain, tetapi ia menganggap mereka sebagai orang yang memperkaya perbendaharaan jiwanya. Murid merupakan sumber inspirasi dan semangat hidupnya. Ada saatnya guru bersikap lembut penuh kasih, dan ada saatnya guru harus bersikap tegas dan keras kepada murid-muridnya. Sikap keras dan lembut itu dilakukan karena pertimbangan kebaikan bagi mereka, bukan atas dorongan nafsu dan egoisme pribadi. Guru yang bijak tidakakan kehabisan ide untuk mengajari muridmuridnya menjadi pribadi yang bermoral tinggi dan bijaksana. Dengan kebijaksanaan, seorang guru akan lebih mudah untuk mendidik dan membimbing murid sesuai dengan keinginannya. Dengan sikap bijaksana akan menjadikan seorang guru sosok pribadi yang utuh.

\section{e. Melayani}

Berdasarkan hasil wawancara dan analisis sikap bijaksana telah mampu ditunjukkan oleh semua informan sebagai tenaga pengajar. Sikap bijaksana yang berasal dari kata hakama-yahkumuhukman-wahikmatan yang berarti teliti, bijak atau arif. Guru yang bijaksana adalah guru yang mampu mengendalikan dirinya dengan baik. Segala tingkah lakunya mencerminkan sosok yang arif dan bijaksana sehingga dapat dipercaya oleh murid-muridnya. Luhur budinya dan lurus ucapannya. Guru yang bijak memandang muridnya sebagai bagian tak terpisahkan dari hidupnya karena itu ia memperlakukan mereka dengan sebaik-baiknya. la tidak menganggap mereka sebagi orang lain, tetapi ia menganggap mereka sebagai orang yang memperkaya perbendaharaan jiwanya. Murid merupakan sumber inspirasi dan semangat hidupnya. Ada saatnya guru bersikap lembut penuh kasih, dan ada saatnya guru harus bersikap tegas dan keras kepada murid-muridnya. Sikap keras dan lembut itu dilakukan karena pertimbangan kebaikan bagi mereka, bukan atas dorongan nafsu dan egoisme pribadi. Guru yang bijak tidakakan kehabisan ide untuk mengajari muridmuridnya menjadi pribadi yang bermoral tinggi dan bijaksana. Dengan 
kebijaksanaan, seorang guru akan lebih mudah untuk mendidik dan membimbing murid sesuai dengan keinginannya. Dengan sikap bijaksana akan menjadikan seorang guru sosok pribadi yang utuh.

\section{Pembahasan Pada Kinerja Tenaga}

Pengajar Di Madrasah Aliyah Negeri

Mojokerto

\begin{tabular}{|c|c|}
\hline $\begin{array}{l}\text { Standar Mutu } \\
\text { Kinerja }\end{array}$ & $\begin{array}{l}\text { Hasil Para Kinerja Tenaga } \\
\text { Pengajar } \\
\text { Di Madrasah Aliyah Negeri }\end{array}$ \\
\hline Kualitas Kerja & \begin{tabular}{ll} 
- & \multicolumn{2}{l}{ Prestasi akademik siswa. } \\
- & Banyak nya siswa \\
mengikuti & kompetisi \\
akademik. &
\end{tabular} \\
\hline Inisiatif & 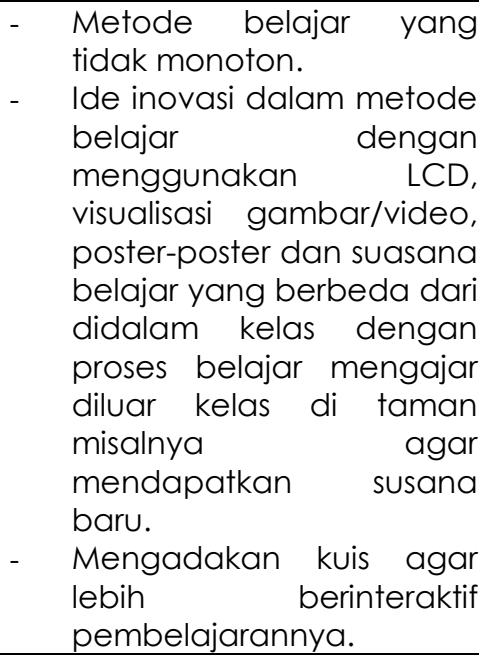 \\
\hline Kerajinan & $\begin{array}{ll}\text { - } & \text { Tepat waktu dalam proses } \\
\text { belajar mengajar. } & \text { Mengajarkan sopan satun. } \\
\text { - } & \text { Mengawali dan } \\
\text { mengakhiri pembelajaran } \\
\text { dengan berdoa. } \\
\text { - } \quad \text { Menjaga kerapian siswa. }\end{array}$ \\
\hline Kehadiran & $\begin{array}{lll}\text { - Jumlah } & \text { kehadiaran } \\
\text { lengkap. } & \end{array}$ \\
\hline
\end{tabular}

Berdasarkan Tabel tersebut dapat dilihat bahwa mutu kinerja tenaga pengajar di Madrasah Aliyah Negeri Mojokerto sudah memenuhi standart kinerja pengajar. Kualitas kerja tenaga pengajar yang menghasilkan prestasi anak didik dan kompetensi mereka dalam mengikuti kompetisi dibidang akademik. Dengan adanya kemampuan anak didik yang bisa berprestasi membuktikan bahwa kualitas tenanga pengajar di Madrasah Aliyah Negeri telah membuahkan hasil.

Implementasi Nilai Tabligh dalam Meningkatkan Kinerja Tenaga Pengajar di Madrasah Aliyah Negeri Mojokerto

Peranan nilai tabligh merupakan hal yang sangat penting bagi seorang tanaga pengajar dalam proses belajar mengajar disekolah. Perlu diketahui bahwa keberhasilan pendidikan terletak pada proses belajar mengajarnya bukan sekedar pencapaian nilai ujian nasional tertinggi. Segala aktivitas kegiatan belajar mengajar seharusnya bermuara pada interaksi siswa dengan gurunya berjalan harmonis. Oleh karena itu pengajar harus memiliki nilai tabligh yang artinya komunikatif dalam menyampaikan ilmu kepada anak didiknya dan mencipatakan pembelajaran sesuai dengan rencana pembelajaran yang interaktif, inspiratif, dan menyenangkan

Dari hasil penelitian Implementasi Nilai Tabligh dalam Meningkatkan Kinerja Tenaga Pengajar di Madrasah Aliyah Negeri Mojokerto dapat disimpulkan bahwa pengajar yang telah mengamalkan nilai tabligh dalam proses belajar mengajarnya mampu meningkatkan kinerja seorang tenaga pengajar. Hal tersebut dapat dilihat dari meningkatnya kualitas seorang guru dalam menyampaikan mata pelajaran kepada para anak didik sehingga memberikan inovasi berupa semangat 
yang tinggi pada anak didik dalam pembelajaran dikelas dan melahirkan anak didik yang tidak hanya berprestasi dalam bidang akademik saja tetapi juga dari segi akhlaknya. Hal tersebut juga berdampak pada tingkat kerajinan anak didik dalam kedisiplinan waktu dengan berkurangnya tingkat keterlambatan saat masuk sekolah sehingga mampu berdampak terhadap jumlah kehadiran absensi siswa terpenuhi dan memenuhi target.

\section{SIMPULAN DAN SARAN}

1. Nilai Tabligh dapat diterapkan dan diamalkan oleh tenaga pengajar baik untuk memperoleh hasil pembelajaran yang memiliki mutu dan kualitas yang baik. Pengamalan tersebut dapat terlihat dari beberapa aspek yang menjadi bagian nilai tabligh yaitu komunikasi, teladan, pendidikan, bijaksana dan melayani. Pengamalan aspek-aspek tersebut telah dilakukan oleh tenaga pengajar dalam melakukan proses pembelajaran untuk tercapainya tujuan sekolah tersebut.

2. Pengamalan nilai tabligh oleh tenaga pengajar telah dilakukan dengan baik. Penerapan aspek-aspek yang menjadi bagian dari nilai tabligh yang mampu meningkatkan kualitas kinerja dari tenaga pengajar. Peningkatan kinerja tersebut dapat terlihat dari proses pembelajaran yang mampu meningkatkan semangat anak didik untuk mengikuti proses pembelajaran di kelas, materi palajaran mampu disampaikan dengan baik oleh setiap tenaga pengajar, pemahaman materi yang diterima anak didik cukup baik yang menjadikan anak didik lebih berprestasi dan berhasil dalam menimba ilmu serta berakhlak mulia.

3. Aspek-aspek yang menjadi bagian dari nilai tabligh telah dilaksanakan dengan baik oleh tenaga pengajar meliputi indikator tabligh yakni meliputi komunikasi, teladan, pendidikan, bijaksana dan melayani. Dan standar kinerja pengajar yang bermutu meliputi kualitas kerja, inisiatif, kerajinan dan kehadiran. Keempat aspek tersebut telah dilakukan dengan baik oleh tenaga pengajar dalam melaksanakan tugas dan tangung jawab di sekolah.

4. Penerapan nilai tabligh dalam proses pembelajaran yang dilakukan oleh tenaga pengajar akan mampu menghasilkan sumberdaya manusia yang bermutu dan berkualitas. Sumberdaya manusia yang bermutu dan berkualitas akan mampu meningkatkan kondisi ekonomi baik bagi diri sendiri maupun bagi bangsa dan negara.

\section{SARAN}

1. Terkait

- Untuk selalu mengamalkan nilai-nilai bekerja Islam dalam melaksanakan tugas bekerja agar mampu memperoleh hasil yang baik untuk sekolah berbasis Islam maupun bagi tenaga pengajar di sekolah tersebut.

- Seorang tenaga pengajar agar selalu mengamalkan nilai tabligh untuk 
meningkatkan kinerja pengajar dan mampu menghasilkan proses pembelajaran yang bermutu bagi anak didik dan tenaga pengajar tersebut.

2. Peneliti Selanjutnya

Bagi peniliti selanjutnya agar lebih mengembangkan penelitian ini berkaitan dengan pengamalan nilai-nilai Islam dalam bekerja dan hasil penelitian dapat bermanfaat bagi masyarakat umum.

\section{DAFTAR PUSTAKA}

Abdulrahim, Muhammad Imaduddin. 1995. Islam Sistem Terpadu. Jakarta: Sari Insan.

Agung, Dr. Iskandar. 2001. Meningkatkan Kreativitas Pembelajaran bagi Guru. Jakarta: Bestari Buana Murni.

Al-Quran Terjemah, 2006. Al-Quran dan Terjemahnya. CV . Pustaka Agung

Asifudin, DR. Ahmad Janan. 2004. Ełos Kerja Islam. Surakarta: Muhammadiyah University Press.

Aziz M.Si, Dr. Hamka Abdul. 2012. Karakter Guru Profesional Melahirkan Murid Unggul Menjawab Tantangan Masa Depan. Jakarta: Al-Mawardi Prima.

Hafidhuddin, K.H. Didin.2003.Islam Aplikatif. Jakarta: Gema Insani Press.

Hafidhuddin, Didin dan Henri Tanjung. 2003. Manajemen Syariah Dalam Praktek. Jakarta: Gema Insani.

Heidrahman dan Saud Husnan. 1990. Manajemen Sumber Daya Manusia dan Perilaku Organisasi. Jakarta: PT. Rineke Cipta.
Pusat Pengkajian dan Pengembangan Ekonomi Islam. 2008. Ekonomi Islam. Jakarta: PT. Raja Grafindo Pusaka.

Sedarmayanti. 2008. Manajemen Sumber Daya Manusia (Reformasi Birokrasi dan Manajemen Pegawai Negeri Sipil). Bandung: Refika Aditam.

Soewardi, Herman. 2000. Mempersiapkan Kelahiran Sains Tauhidullah. Bandung:Tasmara, Toto. 2001. Kecerdasan Ruhaniah (Transcendental Intelligence). Jakarta: Gema Insani. . 2002. Membudayakan Etos

Kerja Islam. Jakarta: Gema Insani. Toto. 2006. Kepemimpinan

Berbasis Spiritual (Spiritual Centered Leaderdhip). Jakarta: Gema Insani. UndangUndang RI No.22 Tahun 2003 tentang Sistem Pendidikan Nasional. Yin, Robert K. 2011. Studi Kasus (Desain \& Metode). Jakarta: PT. Raja Grafindo Persada.

http://www.mansookomojokerto.sch.i 